Розділ І. Ціннісні орієнтири духовно-інтелектуального виховання, розвиток духовно-інтелектуальних якостей особистості в умовах співпраці й інклюзії

\title{
ПОЗААУДИТОРНА ДІЯЛЬНІСТЬ ЗДОБУВАЧІВ ВИЩОЇ ОСВІТИ У КЛУБНИХ ОБ'ЄДНАННЯХ ПЕДАГОГІЧНИХ ЗАКЛАДІВ ВИЩОЇ ОСВІТИ
}

\author{
Чубукіна О. М.
}

здобувач третього (освітньо-наукового) рівня вищої освіти кафедри освітології та інноваційної педагогіки, Харківський національний педагогічний університет імені Г.С. Сковороди, м. Харків, Україна

Стаття присвячена аналізу позааудиторної діяльності здобувачів вищої освіти у формі клубних об 'єднань. Автором визначені важливі завдання, щуо виконують клуби. А саме-багатогранний розвиток особистості майбутнього вчителя та створення вільної неформальної атмосфери мпілкування.

Ключові слова: позааудиторна діяльність, клубні об 'єднання, студентські клуби, гуртки.

The article is devoted to the analysis of extracurricular activities of higher education students in the form of club associations. The author identifies important tasks performed by clubs. Namely, the multifaceted development of the future teacher's personality and the creation of a free informal atmosphere of communication.

Key words: extracurricular activities, club associations, student clubs, clubs.

Освітня програма у педагогічних закладах вищої освіти спрямована на підготовку працьовитих і компетентних майбутніх учителів, формування всебічно розвиненої, творчої та креативної особистості, інтегрованої у сучасне суспільство і націленої на вдосконалення цього суспільства. Важливим способом організації ефективного навчання $\epsilon$ створення єдиної системи аудиторної та позааудиторної роботи зі здобувачами вищої освіти.

Невід'ємним компонентом системи професійної освіти, що дозволяє сформувати компетентного фахівця, є позааудиторна діяльність студентів, у процесі якої можна отримати теоретичні знання, сформувати практичні навички і загальнокультурні та професійні компетенції.

За визначенням В. Коваля, позааудиторна робота є необхідною складовою навчально-виховного процесу, протягом якої студент самостійно займається виконанням навчальних завдань, творчих робіт 
професійного характеру, а також професійною самоосвітою та самовдосконаленням.

Під позааудиторною діяльністю ми розуміємо організацію вільного від навчальних занять часу, спрямовану на розвиток креативності, ініціативності, професійних компетенцій, сприяння соціальному становленню й самореалізації здобувачів вищої освіти.

Організація діяльності клубних об’єднань у педагогічних 3 ВО $є$ однією з форм позааудиторного виховання студентської молоді. Головними чинниками є організація різних напрямків позааудиторної діяльності студентів, створення умов для роботи гуртків і творчих колективів студентської молоді, забезпечення можливостей самореалізації та творчості здобувачів вищої освіти.

Клубні об’єднання у педагогічних ЗВО, а саме студентські клуби, молодіжні центри, студії дозвілля, волонтерські загони, наукові гуртки, гуртки художньої самодіяльності, створюють можливість багатогранного розвитку майбутнього вчителя, зміни видів діяльності, завдяки чому з'являється змога визначати свій життєвий шлях відповідно до соціокультурної ситуації. У процесі позааудиторної діяльності учасники гуртків спільно з керівниками або викладачами працюють над створенням спільної ідеї або творчого продукту з подальшою демонстрацією його суспільству (організація та проведення наукових конференцій, олімпіад, фестивалів, спортивних і творчих заходів).

Важливим аспектом позааудиторної діяльності у клубних об'єднаннях педагогічних ЗВО є специфічна атмосфера, яка характеризується високим ступенем власної внутрішньої свободи учасників гуртків, зниженням значення офіційного боку відносин, розкутістю, володіє великими можливостями для самовдосконалення студентської молоді. Основними мотивами участі молоді у клубних об’єднаннях є такі: знайти нових друзів чи однодумців за інтересами, встановити корисні соціальні контакти, вийти зі стану самотності, цікаво провести вільний час, розважитися.

Отже, позааудиторна діяльність здобувачів вищої освіти у клубних об'єднаннях педагогічних ЗВО є сприятливою сферою розвитку особистості, бо насамперед забезпечує активізацію суб'єктної позиції студентів; стимулює взаємодію і спілкування з однолітками, викладачами та керівниками гуртків; виховує всебічно розвиненого, компетентного майбутнього вчителя. 
Розділ І. Ціннісні орієнтири духовно-інтелектуального виховання, розвиток духовно-інтелектуальних якостей особистості в умовах співпраці й інклюзії

\section{Список використаних джерел:}

1. Коваль В. Ю. Система позааудиторної діяльності студентів вищих навчальних закладів [Електронний ресурс] Наукові праці Донецького національного технічного університету. Серія «Педагогіка, психологія, соціологія». 2009 № 6. С. 19-23. Режим доступу : http://www.nbuv.gov.ua/ portal/soc_gum/Npdntu_pps/2009_6/koval.pdf. (13.10.2021)

2. Козліковська Н. Я. Позааудиторна робота як складова вищої освіти [Електронний ресурс] Режим доступу до ресурсу : http:/www.vmurol.com.ua/ upload/Naukovo_doslidna\%20robota/Elektronni_vidanny a/Act problemi/2008/2/39.pdf (15.10.2021) 